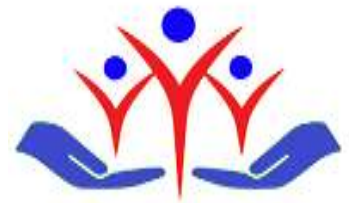

\title{
Prevalence of malnutrition / malnutrition risk in cancer patients: experience of an oncology outpatient clinic in Turkey
}

Kanser hastalarında malnutrisyon / malnutrisyon riski prevalansı: Türkiye'de bir onkoloji polikliniğinin deneyimi

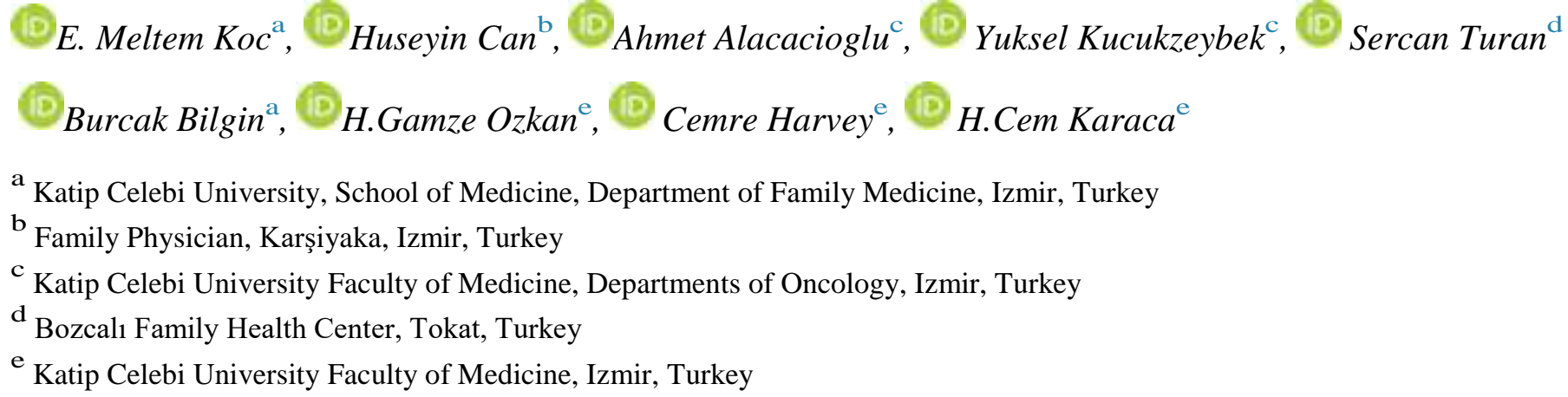

\begin{abstract}
Introduction: The objective of this study is to determine the prevalence of malnutrition risk (MR)/malnutrition (MN) in cancer patients using MNA.

Methods: This observational study was conducted with cancer patients in the Izmir Katip Celebi University Ataturk Training and Research Hospital Medical Oncology Outpatient Clinic. Demographic data, daily functional status according to the Eastern Cooperative Oncology Group (ECOG), nutritional status according to Mini Nutrition Assessments (MNA) and anthropometric measurements obtained with TANITA Body Composition Analyzer Model TBF-300 (TANITA) were used in the evaluation of patients.

Results: The study enrolled 296 oncology patients. The mean age was $58.34 \pm 11.60$ years. Two hundred and eight (70.3\%) of the patients were women. The most common three tumor types were breast tumors $(43.2 \% ; \mathrm{n}=128)$; gastrointestinal tract tumors $(33.1 \%$; $\mathrm{n}=98)$, genitourinary tract tumors $(10.8 \%$ : $\mathrm{n}=32)$. The mean BMI of the patients was $27.45 \pm 5.75 \mathrm{~m} 2 / \mathrm{kg}$. According to MNA 118 of the patients were in normal nutritional status (39.9\%). 130 of them were at the risk of malnutrition (43.9\%), 48 of them were malnourished (16.2\%).

Conclusion: In cancer patients, the prevalence of malnutrition and malnutrition risk is significantly high, and this may alter the patient's life quality and expectancy. Therefore, the nutritional status of every patient that is diagnosed with cancer should be assessed in early stages of the disease.

Keywords: malnutrition, cancer, Mini Nutrition Assessments
\end{abstract}

ÖZ

Giriş: Bu çalışmanın amacı, kanser hastalarında malnutrisyon riskini (MR) / malnütrisyon(MN) prevalansını Mini Nutrisyonel Değerlendirme(Mini Nutrition Assessments (MNA)) testi kullanarak saptamaktır.

Yöntem: Bu gözlemsel çalışma, İzmir Katip Çelebi Üniversitesi Atatürk Eğitim ve Araştırma Hastanesi Tıbbi Onkoloji Polikliniği'nde kanser hastaları ile yürütülmüştür. Hastaların değerlendirilmesinde demografik veriler, Doğu Kooperatif Onkoloji Grubuna (ECOG) göre günlük fonksiyonel durum, Mini Nütrisyon Değerlendirmelerine (MNA) göre beslenme durumu ve TBIF-300 (TANITA) TANITA Vücut Kompozisyonu Analiz Edici Model ile elde edilen antropometrik ölçümler kullanıldı.

Bulgular: Çalışmaya, 296 onkoloji hastası dâhil edilmiştir. Ortalama yaş $58.34 \pm 11.60$ yıl idi. Hastaların 228 (\% 70,3$)$ 'i kadındı. En yaygın üç tümör türü meme tümörleri ( $\% 43,2 ; n=128)$; gastrointestinal sistem tümörleri (\% 33.1, $\mathrm{n}=98)$, genitoüriner yol tümörleriydi $(\% 10,8: \mathrm{n}=32)$. Hastaların ortalama VKİ'si $27,45 \pm 5,75$ $\mathrm{m}^{2} / \mathrm{kg}$ idi. MNA'ya göre hastaların 118(\% 39,9)'inin beslenmesi normaldi.130(\% 43,9)'u malnütrisyon riski altında, 48(\% 16,2).'i yetersiz beslenmekteydi

Sonuç: Kanser hastalarında malnütrisyon ve malnutrisyon riski prevalansı belirgin olarak yüksektir ve bu durum hastanın yaşam kalitesini ve beklentisini değiştirebilir. Bu nedenle, kanser teşhisi konan her hastanın beslenme durumu, hastalığın erken safhalarında değerlendirilmelidir.

Anahtar Kelimeler: malnutrisyon, kanser, Mini Nutrisyonel Değerlendirme

Submission: Dec 18, 2017

Acceptance: Feb 08, 2018

E-Mail: meltemnuzumlali@yahoo.com

Correspondence: Esra Meltem Koc, MD

Izmir Katip Celebi University, School of Medicine, Departments of Family Medicine, Izmir, Turkey

www.fppc.com.tr 


\section{Introduction}

Cancer is a serious public health problem that 8.2 million people die from every year, an estimated $13 \%$ of all deaths worldwide [1]. One of the most important problems in cancer patients is malnutrition. The nutritional condition in which the lack of energy, protein, and other nutrients causes significant adverse effects on tissue/body form, function and clinical outcome [2]. Estimated malnutrition rates in patients with cancer may differ depending on the location, stage and type of cancer; the kind of treatment and the method used to identify the situation. The prevalence of malnutrition can vary between $9 \%$ in urological cancers, and $46 \%$ in lung cancers; however, in patients with pancreatic cancer this rate may rise to $85 \%$ [3]

Malnutrition has negative effects on life quality, disease prognosis and survival'. Malnourished cancer patients have more treatment related adverse reactions than well-nourished patients do [3]. The mortality and morbidity of patients with cancer -related malnutrition is increased [4]. Cancerassociated malnutrition may lead to poor quality of life, diminished chemotherapy response, higher chemotherapy-related toxicity, impaired immune competence, low performance status and muscle function, higher risk of post-operative complications, longer stay in hospital, higher prescription and consultation costs, and shorter survival [3].

To detect malnutrition and to assess malnutrition risk in patients with cancer, anthropometric measures (weight, body mass index; BMI, skin fold and circumferences of the extremities) and also some specialized screening and assessment tests are used[5,6]. Nutritional Risk Screening 2002 (NRS2002); Subjective Global Assessment and Mini Nutrition Assessments (MNA) are the most commonly used tools [5, 6].

MNA was developed with the goal to evaluate the nutritional condition of elderly patients in outpatient clinics, hospitals, or nursing homes. Its purpose is to assess malnutrition risk in order to facilitate timely nutritional interventions when needed [8]. The test encompasses anthropometric measurements (weight, height, and weight loss), global assessment (life style, mobility, and medications), dietary questions and subjective evaluation (self -perception of health and nutrition) [8]. In this study, our goal is to ascertain the prevalence of malnutrition risk (MR)/malnutrition (MN) in cancer patients using MNA.

\section{Methods}

\section{Study design and patients}

This observational study enrolled cancer patients in the Izmir Katip Celebi University Ataturk Training and Research Hospital Medical Oncology Outpatient Clinic. Demographic data, daily functional status determined by the Eastern Cooperative Oncology Group (ECOG), nutritional status according to MNA, and anthropometric measurements obtained with TANITA Body Composition Analyzer Model TBF-300 (TANITA, Tokyo, Japan) were used to evaluate the patients. MNA is an 18-item-screening test including a short form with six questions (MNA-SF) and a second part with 12 questions [6]. The sum of the MNA score is interpreted as follows: MNA $\geq 24$ reflects adequate nutritional status, MNA $\leq 17$ reflects protein calorie under nutrition, and MNA between 17 and 23.5 reflects at risk for malnutrition [9].

The ECOG Scale of Performance Status is a subjective score developed to evaluate the extent of clinical involvement that the tumor inflicts on the patient (nutritional risk assessment systematic review) and describes levels of functioning in terms of their capacity to take care of themselves, their daily activities and physical competence (walking, working, etc.). It is also used as a diagnostic factor for survey in cancer patients. The ECOG PS is scored as follows: Grade 0 , fully active, able to carry on all pre -disease performance without restriction; Grade 1 , restricted in physically strenuous activity but ambulatory and able to carry out work of a light or sedentary nature, for example, light house work, office work; Grade 2, ambulatory and capable of all self -care but unable to carry out any work activities, up and about more than $50 \%$ of waking hours; Grade 3 , capable of only limited selfcare, confined to bed or chair more than $50 \%$ of waking hours; Grade 4, completely disabled and cannot carry on any self -care, totally confined to bed or chair, and Grade 5, dead [10,11].

The TANITA body -fat analyzer is an innovative system that predicts body fat based on the principle of bioelectrical impedance analysis. A comparative analysis of the anthropometric parameters (weight -W, height $-\mathrm{H}$, body mass index (BMI), middle upper arm circumference (MUAC), tricipital skinfold thickness (TSTI) and biochemical parameters (proteins, albumin) was performed. TANITA can be used to assess fat mass (FM, kg and \%), fat-free mass (FFM, kg), muscle mass (MM, kg), and total body water (TBW, \%) [1Hata! Başvuru kaynağı bulunamadı.].

\section{Statistical analysis and ethics}

Statistical analyses were conducted using the demo version of Statistical Package for Social Science 20.0 (SPSS) statistics program. Statistical significance was set at $\mathrm{p}<0.05$. The descriptive analyses of the normally distributed variables were presented as mean and standard deviation. Categorical data was assessed using the Chi-square test or Fisher's exact test. The Student's t test or Mann Whitney U test were used to analyze continuous variables where appropriate. The capacity of the MNA screening test in predicting MN/MR was analyzed using ROC curve analysis. In cases where a significant cut-off value appeared, the sensitivity and specificity have been presented.

The ethical approval was obtained from the Ethical Commission of the Izmir Katip Celebi University Ataturk Training and Research Hospital (13.08.2015, no 152).

\section{Results}

The study enrolled 296 oncology patients. The mean age \pm standard deviation (SD) was $58.34 \pm 11.60$ years. Two hundred and eight (70.3\%) of the patients were women. The most common tumor types were breast tumors $(43.2 \% ; n=128)$; gastrointestinal tract tumors $(33.1 \%$; $n=98)$, genitourinary tract tumors $(10.8 \% ; n=32)$; respiratory tumors $(6.8 \% ; n=9)$ and neural system tumors $(2 \%)$; the most common types of cancer according to organ involvement were breast cancer $(43.2 \%)$, colon cancer $(14.9 \%)$, stomach cancer $(7.4 \%)$, ovarian cancer $(4.7 \%)$, chest, rectal and pancreatic cancer (3.7\%) and endometrial cancer (2.3\%). The socio-demographic properties of the patients is shown in Table 1. 
Table 1. Properties of the patients

\begin{tabular}{lccc}
\hline & Female & Male & $\boldsymbol{p}$-value \\
\hline Age(years) & $56.77 \pm 11.91$ & $62.06 \pm 9.95$ & $<\mathbf{0 . 0 0 1}$ \\
BMI(kg/m ${ }^{2}$ ) & $28.67 \pm 5.72$ & $24.56 \pm 4.71$ & $<\mathbf{0 . 0 0 1}$ \\
Living place & & & \\
$\quad$ Rural & $21.2(\%)$ & $29.5(\%)$ & 0.120 \\
$\quad$ Urban & $78.8(\%)$ & $70.5(\%)$ & \\
Smoking status & $8(0-70)$ & $40(0.5-110)$ & $<\mathbf{0 . 0 0 1}$ \\
Tanita Body Composition Analyzer & & & \\
$\quad$ Fat mass & $25.80 \pm 9.95$ & $14.85 \pm 8.08$ & $<\mathbf{0 . 0 0 1}$ \\
$\quad$ Fat percentage & $35.5(3-406)$ & $19.45(3-38.30)$ & $<\mathbf{0 . 0 0 1}$ \\
$\quad$ Muscle mass & $43(33.2-65.6)$ & $53(36.7-78.9)$ & $<\mathbf{0 . 0 0 1}$ \\
$\quad$ Bone mass & $2.3(1.8-3.5)$ & $2.8(2-4.1)$ & $<\mathbf{0 . 0 0 1}$ \\
$\quad$ Total bone weight & $31.9(22.9-50.4)$ & $39.05(29.3-56.9)$ & $<\mathbf{0 . 0 0 1}$ \\
$\quad$ Total bone weight percentage & $44.7(30.4-69)$ & $55.35(44.2-82)$ & $<\mathbf{0 . 0 0 1}$ \\
\hline
\end{tabular}

\section{Prevalence of malnutrition}

The mean BMI of the patients was $27.45 \pm 5.75 \mathrm{~kg} / \mathrm{m}^{2}$. There was a statistically significant relation between BMI and gender. The mean BMI of the women and men was $28.67 \pm 5.72$ and $24.56 \pm 4.71 \mathrm{~kg} / \mathrm{m}^{2}$ respectively.

According to MNA 118 of the patients were in normal nutritional status (39.9\%), 130 of them were at the risk of malnutrition (43.9\%). 48 of them were malnourished (16.2\%). The prevalence of malnutrition was $18.8 \%$ in genitourinary tract tumors; $5.5 \%$ in breast tumors; $23.5 \%$ in gastrointestinal tumors and $45.0 \%$ in respiratory system tumors. MNA results of the cancer patients according to gender is shown in Table 2 . The malnutrition risk and malnutrition is significantly higher in female than men (Table 3).

Table 2. MNA results of the cancer patients according to gender

Female, n (\%) $\quad$ Male, n (\%) $\quad$ Total, n (\%)

Has food intake declined over the past three months due to loss of appetite, digestive problems, chewing or swallowing difficulties?

Severe decrease in food intake

Moderate decrease in food intake

No decrease in food intake

Involuntary weight loss during the last 3 months?

$\begin{array}{rr}\text { No weight loss } & 133(44.9) \\ \text { Weight loss between } 1 \text { and } 3 \mathrm{~kg} & 28(9.5) \\ \text { Weight loss greater than } 3 \mathrm{~kg} & 42(14.2) \\ \text { Does not know } & 5(1.7)\end{array}$

Bed or chair bound

0

12(4.1)

$196(66.2)$

$25(8.4)$
$52(17.6)$
$131(44.3)$

$131(44.3)$

33(44.9)

(14.2)

$18(6.1)$
$28(9.5)$
$42(14.2)$

42(14.2)

29(9.8)

45(15.2)

0

1(0.3)

6(2.0)

81(27.4)

35(11.8)

53(17.9)

13(4.4)

28(9.5)

47(15.9)

99(33.4)

No psychological problems

Body mass index (BMI)
4(1.4)

11(3.7)

5(1.7)

10(3.4)

23(7.8)

176(59.5)
$11(3.7)$

56(18.9)
43(14.5)

162(54.7)

277(93.6)

120(40.5)

176(59.4)

52(17.6)

98(33.1)

146(49.3)

232(78.4) 
Table 3. The relationship between MNA results and gender

\begin{tabular}{lcccc}
\hline MNA Screening Score & Female, $\mathbf{n}(\boldsymbol{\%})$ & Male, $\mathbf{n}(\boldsymbol{\%})$ & Total, $\mathbf{n}(\boldsymbol{\%})$ & $\mathbf{p}$ \\
\hline Normal nutritional status & $91(30.7)$ & $27(9.1)$ & $118(39.9)$ & \\
Malnutrition risk & $95(32.1)$ & $35(11.8)$ & $130(43.9)$ & $<\mathbf{0 0 0 1}$ \\
Malnutrition & $22(7.4)$ & $26(8.8)$ & $48(16.2)$ & \\
\hline
\end{tabular}

The ROC curve analysis of the BMI according to the nutritional status performed showed that the BMI cut off value of $23.55 \mathrm{~kg} / \mathrm{m}^{2}$ indicated $83.1 \%$ sensitivity and $70.8 \%$ specificity for the prediction of MN. (Figure 1 . Area under curve: $0.829, \mathrm{p}<0.001$ ). The area under curve for men was 0.762 $(\mathrm{p}<0.001)$ and a cut off value was $25.25 \mathrm{~kg} / \mathrm{m}^{2}$ with $73.63 \%$ sensitivity and $68.2 \%$ specificity. Area under curve for women was $0.842(\mathrm{p}<0.001)$ and the cut-off value was $21.45 \mathrm{~kg} / \mathrm{m}^{2}$ with $85.5 \%$ sensitivity and $69.2 \%$ specificity.

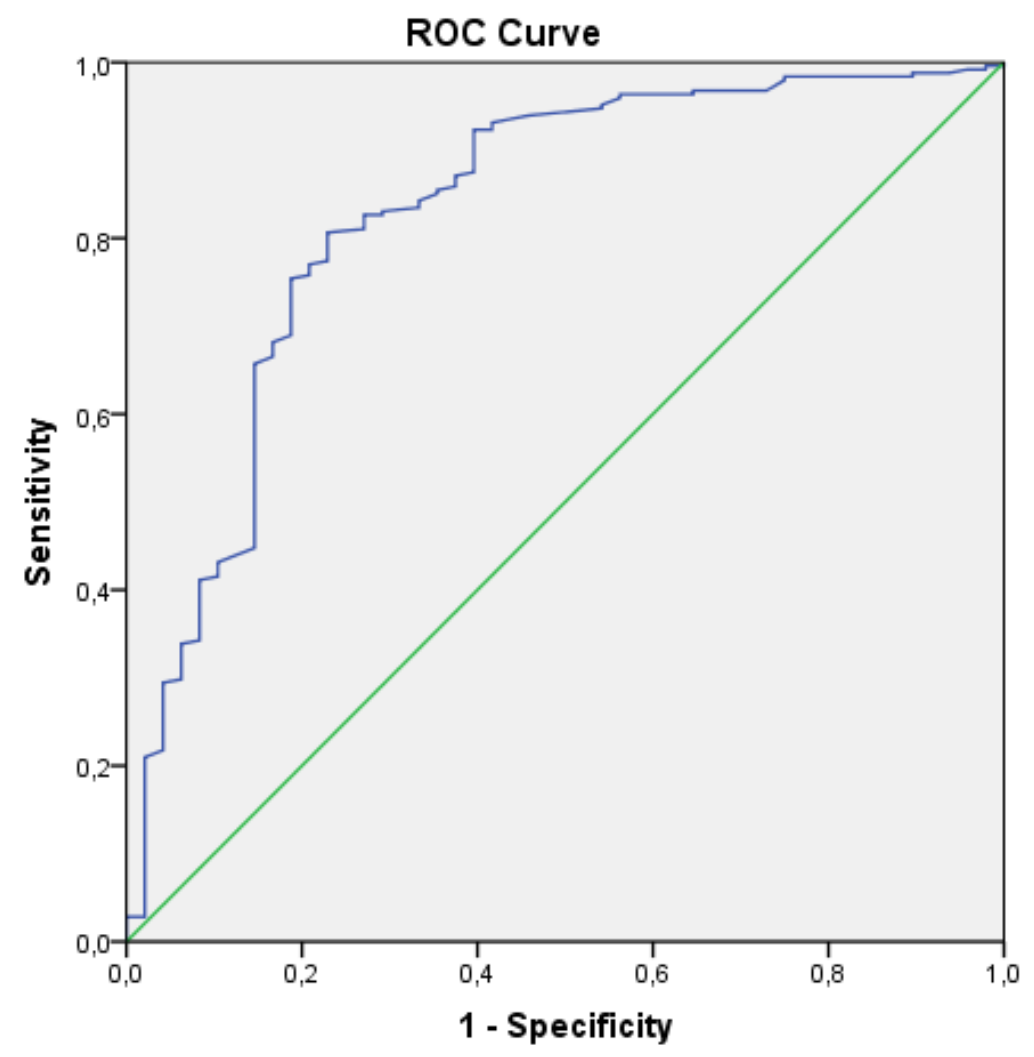

Diagonal segments are produced by ties.

Figure 1. ROC analysis indicating relationship between BMI and nutritional status

\section{Relationship between nutrition status and performance status}

The prevalence of malnutrition was $7.4 \%, 10.3 \%, 27 \%, 10 \%$ and $50 \%$ and the prevalence of malnutrition risk was $40.7 \%, 44.4 \%, 48.6 \% .40 \%$ and $50 \%$ for patients with performance statuses from 0 to 4 .

\section{Nutritional support}

Only $21.4 \%$ of the patients used nutritional support. $12.7 \%$ of the non -malnourished patients and 29.5 of the malnourished patients received nutritional support. Of the patients, $26 \%$ were taking oral supplements; $1 \%$ of them used nasogastric feeding and $0.7 \%$ used PEG for nutritional support. Reasons for using nutritional support were cachexia (152\%), dysphagia (2.4\%) and others (5.7\%).

\section{Discussion}

Malnutrition develops in most cancer patients and it is one of the leading causes of morbidity and mortality in more advanced stages of the disease [13]. The prevalence of malnutrition ranges between $40 \%$ and $80 \%$ among cancer patients [14]. However, the predicted prevalence depends on the location of the tumor, the stage of the disease, the type of treatment and the method used to determine the status of the patient. The frequency of malnutrition varies it is $9 \%$ in urological cancers, $46 \%$ in lung cancers, and $85 \%$ in pancreatic cancers [14]. Earlier studies have shown that the 
frequency of malnutrition is high in gastrointestinal system cancers and low in breast cancers and lymphomas. In our study, the prevalence of malnutrition is $16.2 \%$, when assessed with respect to the localization of the tumor it is $45 \%$ in respiratory tract cancers, $18.8 \%$ in genitourinary system cancers, $5.5 \%$ in breast cancers and $23.5 \%$ in gastrointestinal system cancers.

Advanced stage cancer patients lose weight throughout the course of illness and some experience involuntary weight loss, which causes cancer cachexia. This complex multifactorial syndrome could be associated with factors pertaining to the tumor itself, the host response to the tumor, and anticancer treatments. Malnourished patients experience more treatment-related side effects and morbidity and mortality rates are higher in comparison to patients that are well-nourished [15]. Malnutrition can be the cause of poor prognosis and outcomes, to maintain the effectiveness of anticancer treatment, the capacity to deal with stress and to reduce the side effects of treatment cancer patients must be well -nourished. Within this context, nutritional screening in cancer patients should be identified as the most important step in preventing the development of malnutrition [14]. To improve clinical results and life quality, the inseparable part of cancer therapy should consist of proactive nutritional interventions more than it does of reactive interventions. The goal of nutritional support is to prevent or reverse nutritional deficiencies and to prevent progression to cachexia [15]. Within this context, besides detecting malnutrition in patients with cancer, identifying the malnutrition risk is also important in determining the treatment method and it is associated with prognosis. Studies conducted in our country also show how high the risk of malnutrition is in cancer patients. According to the study performed by Saka and colleagues, the risk for malnutrition is $89 \%$ among cancer patients in hospital [6]. In the study of Korfali and colleagues, $43.4 \%$ of cancer patients are under risk for malnutrition [16]. In our study, the malnutrition risk of cancer patients was determined as $43.9 \%$.

Nutritional screening is performed with the goal to recognize malnourished patients and those that are at significant risk of malnutrition. The use of adequate screening methods is important for effective nutritional interventions and management. In the last 20 years, many screening instruments have been developed but most of these are too complicated for routine use in daily practices [13]. Until the present, no instruments have been devised that are sensitive and specific enough to become the golden standard for the assessment of nutrition [17]. Although there is no generally accepted method for assessing the nutritional status of patients, the assessment should establish the nutritional condition of a subject. It should be a combination of the subjective and objective parameters, clinical, physical, psychological, anthropometric, biochemical, and hematological conditions. In this study, MNA and anthropometric measurements have been used to assess the nutritional condition. Although MNA encompasses the information about the most important parameters for assessing malnutrition such as global assessments like anthropometric measurements (height, weight, weight loss), life style, mobility questions about diet; and the individual's perceptions about their own health and nutrition, it does not address all the parameters required. Individual assessments such as the BMI, weight loss, muscle circumferences and skin fold thickness do not reflect the actual nutritional condition. Therefore, to obtain the best possible result from anthropometric measurements performed to assess the nutritional condition they should be combined with other parameters recommended [17]. The fact that we did not use biochemical and hematological parameters beside MNA and anthropometric measurements may be regarded as a limitation of our study. However, according to the results of the New Mexico Aging Process study, nutritional intake decreases before weight loss occurs and before serum albumin levels decrease, in other words, MNA can be used alone to assess the nutritional condition before the changes in weight and albumin levels occur. In our study, the nutritional status was evaluated using the MNA alone.

The Eastern Cooperative Oncology Group Performance Status (ECOGPS) is a universal indicator used to establish the applicability of chemotherapy in oncology or its eligibility for clinical studies. Besides this, it is among the strongest prognostic factors of survival for patients with advanced cancer [11]. In the study conducted by Cessot and colleagues in which malnutrition was defined as a BMI $<18.5 \mathrm{~kg} / \mathrm{m}^{2}$ or premorbid weight loss higher than $10 \%$ or albuminemia $(<35 \mathrm{~g} / \mathrm{L})$, malnutrition was detected in $43 \%$ of those with performance scores of $0-1$, as $60 \%$ in those with performance scores of 2 , and as $66 \%$ in those with performance scores of 3, however, the difference among the groups in terms of the occurrence of malnutrition was not significant statistically [18]. In our study, the malnutrition frequency was identified as $7.4 \%, 10.3 \%, 27 \%, 10 \%$, and $50 \%$, respectively, depending on the performance status between zero and four. The reason of this difference could have been the fact that Cessot and colleagues evaluated the nutritional status using only one parameter although it is recommended to use many different parameters and in our study, the nutritional status was evaluated using MNA, which assesses a number of parameters.

One limitation of our study is that the MNA instrument has been used in patients older than 65 years of age without considering the recommended age limit of the MNA. The frequency of malnutrition is $15-60 \%$ in the elderly that are in hospital or nursing homes. MNA easily assesses malnutrition in the special group of fragile and elderly patients older than 65 years [8]. As malnutrition is also very frequent in cancer patients and because cancer patients arc also a special patient group resembling the fragile and elderly patients, we considered it appropriate to use MNA to evaluate malnutrition and the malnutrition risk in patients with cancer.

\section{Conclusion}

The prevalence of malnutrition and malnutrition risk are rather high in cancer patients and it has an important effect on the life quality and expectancy. Therefore, the nutritional status of every patient that is diagnosed with cancer should be assessed in early stages of the illness. Ensuring that patients receive adequate nutritional support may improve life quality and prolong survival.

\section{Conflict of interest: none.}

Funding: none

\section{References}

1. World Health Organisation http://www.who.int/cancer/en/ Access time: 12.12 .2016

2. Cutsem EV, Arends J. The causes and consequences of cancer associated malnutrition. Eur J Oncol Nurs. 2005;9 Suppl 2:S51-63. doi: https://doi.org/10.1016/j.ejon.2005.09.007 
3. Van Bokhorst M. Nutritional support strategies for malnourished cancer patients. Eur J Oncol Nurs. 2005;9 Suppl 2:S74-83.e. doi: https://doi.org/10.1016/j.ejon.2005.09.004

4. Argiles JM. Cancer associated malnutrition. Eur J Oncol Nurs. 2005;9 Suppl 2:S39-50. doi: https://doi.org/10.1016/j.ejon.2005.09.006

5. Saka B. Nutrition and Cancer. The 37th National Hematology Congress 19-22 October 2011, Ankara, 82-85

6. Saka B, Ozkaya H, arisik E, Akin S, Akpinar TS, Tufan F, et al. Malnutrition and sarcopenia are associated with increased mortality rate in nursing home residents: A prospective study. Eur Geriatr Med 2016; 7:232-238. doi: https://doi.org/10.1016/j.eurger.2015.12.010

7. Saka B, Kaya O, Ozturk GB, Erten N, Karan MA. Malnutrition in the elderly and its relationship with other geriatric syndromes. Clin Nutr 2010;29:745-748. doi: https://doi.org/10.1016/j.clnu.2010.04.006

8. Vellas B, Guigoz Y, Garry PJ, Nourhashemi F, Bennahum D, Lauque S, et al. The Mini Nutritional Assessment (MNA) and its use in grading the nutritional state of elderly patients. Nutr 1999;15:116 -122. PMID:9990575

9. Sarikaya D, Halil M, Kuyumcu ME, Kilic MK, Yesil Y, Kara O, et al. Mini nutritional assessment test long and short form are valid screening tools in Turkish older adults. Arch Gerontol Geriatr 2015;61:56-60. doi: https://doi.org/10.1016/j.archger.2015.04.006

10. ECOG-ACRIN Cancer Research Group. http://ecog-acrin.org/resources/ecog-performance-status Access time: 12.12 .2016

11. Kim YJ, Hui D, Zhang Y, Park JC, Chisholm G, Williams J, et al. Differences in performance status assessment among palliative care specialists, nurses, and medical oncologists. J Pain Symptom Manage. 2015;49(6):1050-1058. doi: https://doi.org/10.1016/j.jpainsymman.2014.10.015

12. Chincesan MI, Mărginean CO, Voidăzan S. Assessment of body composition in a group of pediatric patients with cancer: a single romanian center experience. J Pediatr Hematol Oncol. 2016;38(7):217-222. doi: https://doi.org/10.1097/MPH.0000000000000586

13. Davies M. Nutritional screening and assessmnet in cancer-associated malnutrition. Eur J Oncol Nurs. 2005;9 Suppl 2:S64-73. doi: https://doi.org/10.1016/j.ejon.2005.09.005

14. Wie GA, Cho YA, Kim SY, Kim SM, Bae JM, Joung H, et al. Prevalence and risk factors of malnutrition among cancer patients according to tumor location and stage in the National Cancer Center in Korea. Nutr. 2015;26: 263-268. doi: https://doi.org/10.1016/j.nut.2009.04.013

15. Marian AE. Nutritional support strategies for malnourished cancer patients. Eur J Oncol Nurs.2005;9:74-83. doi: https://doi.org/10.1016/j.ejon.2005.09.004

16. Korfali G, Gündoğdu H, Aydintuğ S, Bahar M, Besler T, Moral AR, et al. Nutritional risk of hospitalized patients in Turkey. Clin Nutr.2009; 28(5):533-537. doi: https://doi.org/10.1016/j.clnu.2009.04.015

17. Fruchtenicht AVG, Poziomyck AK, Kabke GB, Loss SH, Antoniazzi JL, Steemburgo T, et al. Nutritional risk assessment in critically ill cancer patients: systematic review. Rev Bras Ter Intensiva 2015;27(3):274-283. doi: http://dx.doi.org/10.5935/0103-507X.20150032

18. Cessot A, Coriat R, Mir O, Boudou-Rouquette P, Giroux J, Durand JP, et al. Nutritional Status Is Superior to the ECOG Performance Status in Predicting the Dose-Intensity of the GEMOX Chemotherapy Regimen in Patients with Advanced Cancer. Nutr Cancer, 2013;65(8):1254-1257. doi: https://doi.org/10.1080/01635581.2013.830315 